\title{
Zonasi Potensi Pencemaran Bahan Bakar Minyak terhadap Airtanah Bebas (Studi Kasus SPBU 44.552.10 Yogyakarta)
}

\author{
Eni Muryani \\ Teknik Lingkungan, Fakultas Teknologi Mineral \\ Universitas Pembangunan Nasional "Veteran" Yogyakarta \\ e-mail:enimuryani@gmail.com
}

\begin{abstract}
Abstrak
Kasus kebocoran tangki penyimpan bawah tanah ataupun pipa saluran Bahan Bakar Minyak (BBM) kerap terjadi dan menyebabkan pencemaran airtanah bebas. Salah satu kasus terjadi di Stasiun Pengisian Bahan Bakar Minyak untuk Umum (SPBU) 44.552.10 Yogyakarta. Penelitian ini bertujuan untuk membuat zonasi potensi pencemaran BBM terhadap airtanah bebas di lingkungan sekitar SPBU 44.552.10. Metode yang digunakan adalah metode LeGrand yang spesifik untuk kasus pencemaran airtanah bersumber dari 1 titik. Pertama, dilakukan pengukuran kedalaman muka airtanah pada sejumlah sumur warga untuk mendapatkan gambaran arah aliran airtanah. Kedua, dilakukan penilaian dan skoring terhadap 5 faktor lingkungan fisik, yakni: kedalaman muka airtanah, daya serap di atas muka airtanah, permeabilitas akifer, kemiringan muka airtanah, dan jarak horisontal. Zonasi potensi pencemaran airtanah diperkirakan berdasarkan skor total dari lima faktor tersebut di tiap titik sampling dan arah aliran airtanah. Hasil penelitian menunjukkan sumur yang terletak 0-2 km di bagian selatan dan barat daya SPBU 44.552.10 berpotensi mengalami pencemaran BBM. Potensi terbesar berada pada radius $45 \mathrm{~m}$.
\end{abstract}

Kata kunci: Airtanah bebas, potensi pencemaran BBM, SPBU

\section{Pendahuluan}

Tangki penampung BBM di SPBU merupakan salah satu sumber yang dapat menyebabkan pencemaran dalam airtanah. Tangki penyimpan BBM bawah tanah (Underground Storage TankUST) yang terbuat dari baja mudah bocor atau rembes karena proses karat yang terjadi di dalam tanah (Kamil dalam Pikiran Rakyat, 2004). Standar Operasional yang dibuat sedemikian rupa oleh Pertamina untuk SPBU tidak menjamin SPBU akan bebas dari risiko bocor dan mencemari lingkungan. Faktor bencana alam dapat memperbesar risiko terjadinya kebocoran tangki. Gempabumi dapat meretakkan tangki timbun dan tanah di sekitarnya tanpa disadari oleh semua orang hingga bocoran bensin sampai ke sumur warga. Syarat teknis dan operasional yang tidak dipatuhi oleh pengelola SPBU juga dapat memperbesar risiko kebocoran.

Bahan bakar minyak yang bocor dari tangki penyimpanan dapat menyebabkan berubahnya kualitas airtanah bebas. BBM yang bocor ini akan merembes ke tanah, mengalir mengikuti aliran airtanah, dan mengapung pada permukaan airtanah dangkal. Sebagian BBM terperangkap dalam pori-pori tanah dan terserap ke dalam partikel tanah, sehingga dapat mencemari dan merusak ekosistem yang ada pada tanah dan airtanah di sekitarnya (Notodarmojo, 2005). Kandungan senyawa yang terdapat dalam bahan bakar minyak sangat kompleks dan beragam. Salah satunya adalah senyawa 
hidrokarbon aromatik yang mudah menguap, mudah terbakar, mudah berpindah tempat di lingkungan, tergolong bahan berbahaya beracun (B3), dan bersifat karsinogenik (Fetter, 1999; Notodarmojo, 2005; Soemirat, 2005).

Kasus kebocoran BBM sangat mungkin untuk terjadi lagi di masa yang akan datang di SPBU manapun. Penelitian dilakukan di sekitar area SPBU 44.552.10 yang pernah mengalami kasus kebocoran dan menyebabkan pencemaran air sumur warga di sekitarnya. Daerah sebelah selatan, barat, dan timur SPBU merupakan pemukiman padat penduduk pengguna air sumur, sehingga menimbulkan dampak sosial yang besar saat terjadi kasus kebocoran bahan bakar minyak.

Permasalahan yang diangkat dalam penelitian ini yaitu bagaimana menentukan zonasi yang dapat menggambarkan potensi sebaran spasial pencemaran BBM dari suatu sumber terhadap airtanah bebas di sekitarnya. Pada kasus ini sumber pencemar adalah tangki BBM bawah tanah di SPBU 44.552.10 dengan kedalaman lebih kurang $3 \mathrm{~m}$.

Penelitian ini bertujuan untuk membuat zonasi potensi pencemaran BBM terhadap airtanah bebas berdasarkan 5 faktor fisik alami lingkungan di lokasi penelitian, yakni: kedalaman muka airtanah, daya serap di atas muka airtanah, permeabilitas akifer, kemiringan muka airtanah, dan jarak horisontal dari sumber pencemar.

\section{Metode Penelitian}

Metode yang digunakan adalah metode survei yang secara empiris dikembangkan oleh LeGrand, dengan nilai lima faktor lingkungan fisik sebagai data utama. Data primer yang diperoleh di lapangan maupun melalui analisis di laboratorium dan perhitungan meliputi: kedalaman muka airtanah; peta kontur ketinggian muka airtanah dan arah aliran airtanah (flownets) daerah penelitian; jarak horisontal sumur dengan sumber pencemar; dan kemiringan muka airtanah. Data sekunder yang terkait dengan penelitian ini mencakup: peta rupa bumi skala 1:25.000 lembar Timoho; data sumur bor daerah penelitian; dan peta tanah semi detil skala 1:50.000 lembar Yogyakarta.

Awal penelitian dilakukan dengan cara mengukur kedalaman muka airtanah pada sumur-sumur di lokasi penelitian untuk mendapatkan peta flownets. Kemudian dilakukan penilaian, skoring, dan pemetaan terhadap kedalaman muka airtanah, daya serap di atas muka airtanah, permeabilitas akifer, kemiringan muka airtanah, dan jarak horisontal. Besar kecilnya potensi diperkirakan berdasarkan skor total dari lima faktor yang mempengaruhi pencemaran airtanah. Zonasi potensi pencemaran BBM terhadap airtanah di lokasi penelitian disesuaikan dengan arah aliran airtanah. 
Peta dasar lokasi penelitian bersumber dari peta rupa bumi skala 1: 25.000 lembar Timoho tahun 2001, menggunakan software Arc. GIS. Penentuan sampel sumur yang diukur kedalaman muka airtanahnya menggunakan sistem grid $1 \mathrm{~cm}$ x $1 \mathrm{~cm}$ (metode sampling sistematik). Data kedalaman muka airtanah diperoleh melalui pengukuran sumur langsung di lapangan dengan meteran. Berdasarkan data kedalaman muka airtanah yang diukur dari permukaan tanah dapat diperoleh persebaran tinggi muka airtanah daerah penelitian yang digunakan untuk membuat kontur muka airtanah daerah penelitian. Tinggi muka airtanah merupakan selisih antara ketinggian tempat diatas permukaan air laut dengan kedalaman muka airtanah. Ketinggian tempat di atas permukaan airlaut diperoleh dari kontur pada peta RBI 1: 25.000 yang telah diinterpolasi menggunakan Arc.GIS.

Kedalaman muka airtanah yang dihitung dari dasar tangki didapat dari hasil pengurangan Tinggi Muka Airtanah (TMA) SPBU dengan TMA sumur sampling. Kedalaman muka airtanah dari dasar tangki (jarak tangki timbun ke muka airtanah) diperoleh dari data kedalaman muka airtanah, ketinggian tempat sampling di atas permukaan air laut, ketinggian SPBU di atas permukaan air laut, dan dalamnya tangki dipendam. Ketinggian tempat diperoleh dari peta RBI. Selisih antara tinggi tempat dan kedalaman tangki pendam diistilahkan sebagai TMA SPBU. Diketahui kedalaman pemendaman tangki timbun di SPBU 44.552.10 adalah $3 \mathrm{~m}$ dan tinggi tempat 120 mdpal.

Daya serap di atas muka airtanah ditentukan berdasarkan tekstur tanah pada zona tak jenuh. Tekstur tanah diperoleh berdasarkan pembacaan peta tanah semi detil skala 1:50.000 lembar Yogyakarta. Interpretasi daya serap di atas muka airtanah ditentukan dengan menetapkan kategori seri tanah pada tiap sumur terlebih dahulu. Penetapan tekstur tanah mempertimbangkan kedalaman lapisan tanah. Kedalaman lapisan tanah tergantung dari tinggi tempat dan tinggi dasar tangki di atas permukaan laut. Apabila selisih antara tinggi tempat sampling sumur dan tinggi dasar tangki bernilai negatif maka tekstur tanah lapisan atas yang dipakai. Jika selisihnya bernilai positif, maka teksturnya menyesuaikan kedalaman tanah yang ada pada keterangan tekstur tanah di tiap seri tanah.

Permeabilitas akifer ditentukan berdasarkan material penyusun akifer. Material penyusun akifer diperoleh berdasarkan interpretasi data sumur bor yang ada di sekitar lokasi penelitian dan hasil perhitungan konduktivitas hidrolik melalui pumping test di lokasi penelitian. Penentuan materi akifer berdasarkan interpretasi sumur bor memperhatikan ketinggian tempat sumur bor, kedalaman sumur bor, dan ketinggian muka airtanah tiap sumur sampling.

Kemiringan muka airtanah diperoleh dari peta kontur muka airtanah yang didapatkan. Kemiringan muka airtanah (gradien hidrolik) merupakan selisih perbedaan tinggi muka airtanah satu dengan lainnya. Persentase kemiringan muka airtanah dapat dicari dengan menggunakan rumus: 


$$
i=\frac{d h}{d s} \times 100 \%
$$

keterangan:

i : kemiringan muka airtanah (\%)

$\mathrm{dh}$ : perubahan tinggi muka airtanah $(\mathrm{m})$

ds : jarak horisontal antar sumur $(\mathrm{m})$

Penetapan skor kemiringan airtanah juga mempertimbangkan arah aliran airtanah dan arah aliran pencemar (BBM) dalam airtanah.

Perhitungan jarak horisontal sumur dengan sumber pencemar dilakukan melalui peta dengan program Arc. GIS. Dari hasil pembacaan GPS dapat diketahui posisi SPBU 44.552.10 dan sumursumur yang dijadikan titik sampling. Posisi tersebut diplotkan pada peta dan jarak horisontal antara sumber pencemar (tangki di SPBU) dengan sumur dapat diketahui secara otomatis.

Selanjutnya dilakukan skoring pada tiap faktor berdasarkan diagram yang disajikan pada Gambar 1 .

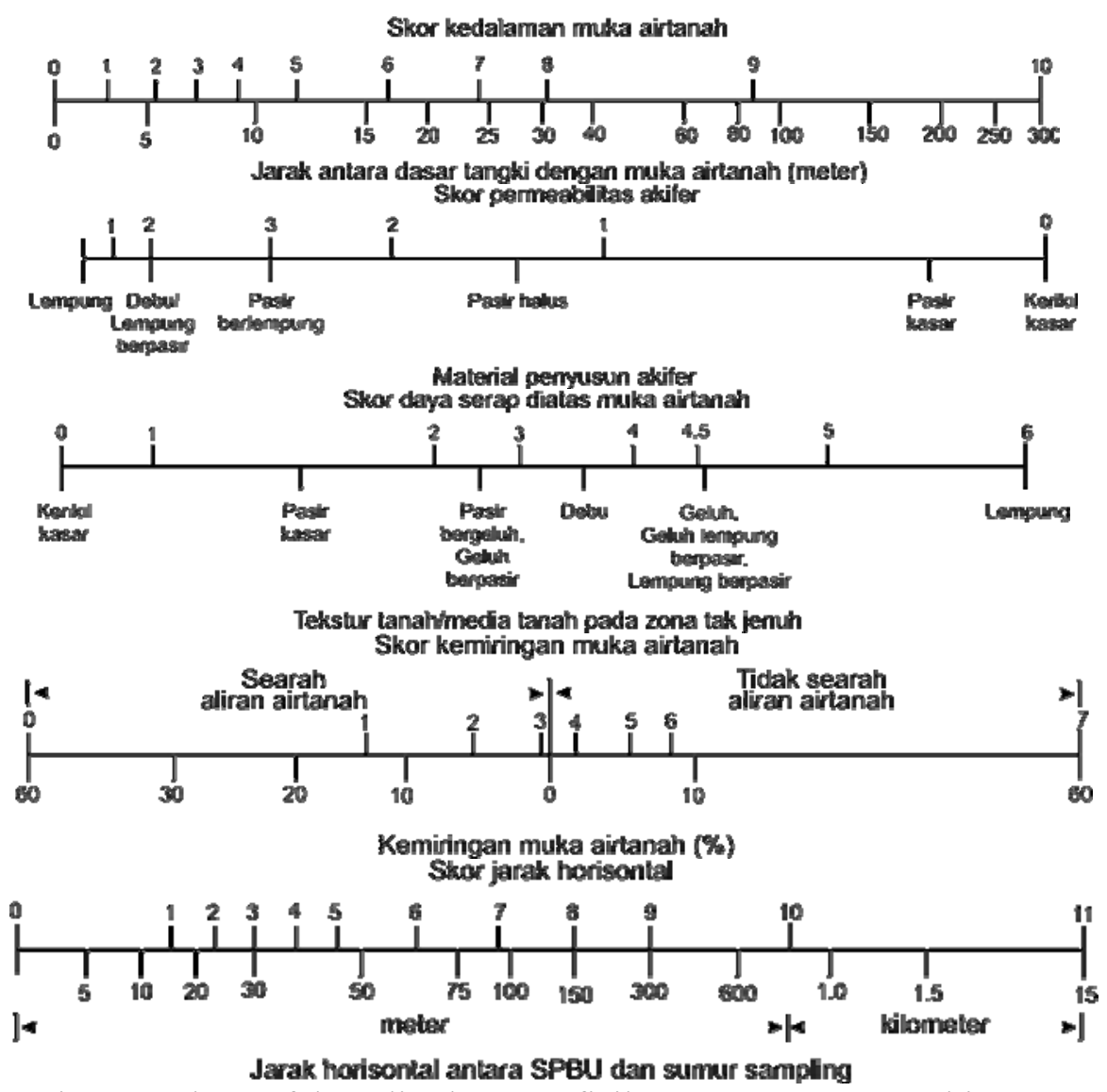

Gambar 1. Diagram skor 5 faktor lingkungan fisik yang mempengaruhi pencemaran BBM terhadap airtanah bebas di sekitar SPBU (LeGrand, 1964 dalam Todd,1980 dan pengembangan)

Kelas potensi pencemaran ditentukan berdasarkan jumlah skor 5 faktor lingkungan fisik yang disajikan pada Tabel 1. Zonasi potensi dan sebaran spasial dibuat berdasarkan kelas potensi dan arah aliran airtanah. 
Tabel 1. Nilai total pengharkatan (skoring) potensi pencemaran airtanah

\begin{tabular}{|c|c|l|}
\hline No. & Skor Total & \multicolumn{1}{c|}{ Kelas potensi pencemaran } \\
\hline 1 & $0-4$ & Sangat besar (sangat mungkin tercemar) \\
\hline 2 & $4-8$ & Besar (dapat atau mungkin tercemar) \\
\hline 3 & $8-12$ & Sedang (mungkin tercemar tetapi sulit) \\
\hline 4 & $12-25$ & Kecil (sangat sulit tercemar) \\
\hline 5 & $25-35$ & Sangat kecil (hampir tidak mungkin tercemar) \\
\hline
\end{tabular}

Sumber: LeGrand, 1964 dalam Todd, 1980 dengan pengembangan

\section{Hasil dan Pembahasan}

Potensi pencemaran BBM terhadap airtanah bebas di lokasi penelitian diperoleh berdasarkan hasil penilaian dan pengharkatan terhadap 5 faktor lingkungan fisik. Penilaian dan skoring lima faktor lingkungan fisik dilakukan terhadap 80 sumur di lokasi penelitian. Dari 80 sumur, yang dapat dikategorikan berpotensi mengalami pencemaran BBM dari SPBU 44.552 .10 hanya 33 sumur. Tabel 2 menunjukkan distribusi frekuensi kelas potensi pencemaran BBM terhadap air tanah di lokasi penelitian.

Tabel 2. Distribusi frekuensi potensi pencemaran BBM terhadap airtanah bebas

\begin{tabular}{|l|c|c|}
\hline \multicolumn{1}{|c|}{ Potensi Pencemaran BBM } & Jumlah Sumur & Persentase (\%) \\
\hline Tidak Berpotensi & 47 & 58,75 \\
\hline Besar & 2 & 2.5 \\
\hline Sedang & 2 & 2.5 \\
\hline Kecil & 25 & 31,25 \\
\hline Sangat Kecil & 4 & 5 \\
\hline Jumlah & 80 & 100 \\
\hline
\end{tabular}

Sumber: hasil perhitungan dan analisis

Tabel 2 memperlihatkan bahwa hanya 41,25\% dari sampel sumur di lokasi penelitian yang berpotensi untuk tercemar BBM jika terjadi kebocoran tangki timbun BBM di SPBU 44.552.10 ditinjau dari aspek lingkungan fisik. Empat puluh tujuh sumur sampling dikatakan tidak berpotensi karena tidak searah dengan arah aliran airtanah. Dari 33 sumur yang berpotensi tercemar BBM, masing-masing 2 sumur yang termasuk kategori berpotensi besar dan sedang. 25 sumur dikategorikan berpotensi kecil dan 4 sumur berpotensi sangat kecil. Daerah yang berpotensi mengalami pencemaran airtanah dari SPBU 44.552.10 terletak di sebelah selatan SPBU dan cenderung ke barat daya. Zonasi pencemaran BBM terhadap airtanah bebas di sekitar SPBU 44.552.10 secara potensial disajikan dalam bentuk peta pada Gambar 3. 


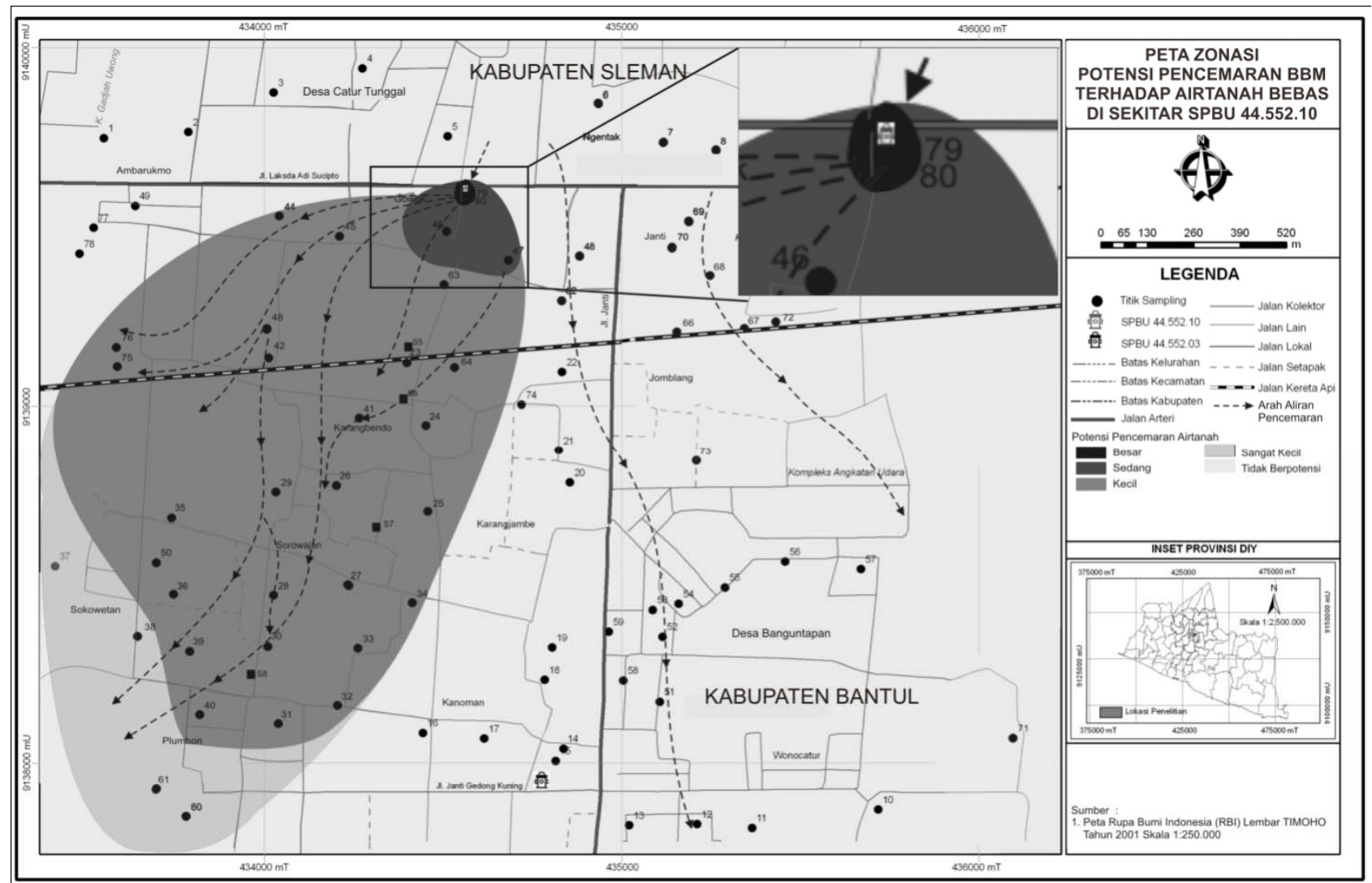

Gambar 3. Peta Zonasi Potensi Pencemaran BBM terhadap Airtanah Bebas di Sekitar SPBU 44.552 .10

Berdasarkan peta pada Gambar 3, daerah yang berpotensi mengalami pencemaran airtanah dari SPBU 44.552.10 berada di bagian selatan, cenderung ke barat daya. Sumur yang terletak pada radius $<45 \mathrm{~m}$ bagian selatan dan barat daya SPBU 44.552.10 memiliki potensi paling besar (dengan kategori berpotensi besar) untuk tercemar BBM. Sumur yang berjarak $<200 \mathrm{~m}$ sebelah selatan dan barat daya SPBU 44.552.10 dikategorikan berpotensi sedang untuk tercemar BBM. Sumur dengan jarak $<1,7 \mathrm{~km}$ termasuk kategori berpotensi kecil, dan sumur-sumur yang letaknya $>1,5 \mathrm{~km}$ termasuk kategori berpotensi sangat kecil. Hal ini terkait dengan pengaruh kelima faktor lingkungan fisik secara bersama dan arah aliran air tanah.

Hasil perhitungan berdasarkan Gambar 3 menunjukkan bahwa hanya 33 (41,25\%) dari 80 sampel sumur di lokasi penelitian yang berpotensi untuk tercemar BBM jika terjadi kebocoran tangki timbun BBM di SPBU 44.552.10. Dari 33 sumur yang berpotensi tercemar BBM, 75,75\% dikategorikan berpotensi kecil; 6,06\% termasuk kategori berpotensi besar dan sedang; 12,12\% berpotensi sangat kecil.

Sumur yang terletak $<45 \mathrm{~m}$ dari SPBU 44.552.10 memiliki potensi besar untuk tercemar BBM. Sumur yang berjarak $<200 \mathrm{~m}$ berpotensi sedang tercemar BBM. Sumur dengan jarak $<1,7 \mathrm{~km}$ berpotensi kecil untuk mengalami pencemaran BBM. Sumur-sumur yang letaknya $>1,5 \mathrm{~km}$ dan searah dengan aliran air tanah potensinya sangat kecil. 
Keterkaitan nilai lima faktor lingkungan fisik terhadap potensi pencemaran BBM pada airtanah di sekitar SPBU 44.552.10 secara garis besar disajikan pada Tabel 3. Nilai tiap faktor diperoleh berdasarkan nilai rata-rata atau kisaran yang menghasilkan kelas potensi pencemaran. Nilai kedalaman yang tercantum pada Tabel 3 merupakan nilai kedalaman muka airtanah dari permukaan tanah.

Tabel 3. Keterkaitan antara faktor lingkungan fisik dengan kelas potensi pencemaran

\begin{tabular}{|c|c|c|c|c|c|}
\hline $\begin{array}{c}\text { Kedalaman } \\
\text { MAT (m) }\end{array}$ & $\begin{array}{c}\text { Media Zona Tak } \\
\text { Jenuh }\end{array}$ & $\begin{array}{c}\text { Media Zona } \\
\text { Jenuh Air } \\
\text { (Akifer) }\end{array}$ & $\begin{array}{c}\text { Kemiringan } \\
\text { MAT (\%) }\end{array}$ & $\begin{array}{c}\text { Jarak } \\
\text { horisontal } \\
(\boldsymbol{m})\end{array}$ & $\begin{array}{c}\text { Potensi } \\
\text { Pencemaran } \\
\text { BBM }\end{array}$ \\
\hline$<5,0$ & kerikil kasar & pasir kasar & $\geq 1,8$ & $\leq 45$ & Besar \\
\hline$>3,0-3,5$ & kerikil kasar & pasir kasar & $\geq 1,8$ & $>45-200$ & Sedang \\
\hline$>0,8-8,0$ & pasir bergeluh & pasir halus & $0,5-2,0$ & $>200-1700$ & Kecil \\
\hline$>3,0-9,0$ & geluh berpasir & $\begin{array}{c}\text { lempung } \\
\text { berpasir }\end{array}$ & $0,8-2,3$ & $>1500-2000$ & Sangat Kecil \\
\hline
\end{tabular}

Sumber: hasil perhitungan dan analisis

Titik sampling dengan kedalaman sumur $<5 \mathrm{~m}$, material zona tak jenuh didominasi oleh kerikil dan batu, material akifer (zona jenuh air) berupa pasir kasar, kemiringan muka airtanah $\geq 1,8 \%$ dan berjarak $<200 \mathrm{~m}$ dari SPBU 44.552.10 dikategorikan berpotensi besar hingga sedang untuk tercemar. Sumur-sumur yang terletak $>200-2000 \mathrm{~m}$ dari SPBU dengan kedalaman $<9 \mathrm{~m}$, kemiringan muka airtanah 0,5-2,3\%, material zona tak jenuh di dominasi oleh pasir bergeluh hingga geluh berpasir, dan material akifernya berupa pasir halus dan lempung berpasir dikategorikan berpotensi kecil dan sangat kecil mengalami pencemaran.

Kondisi hidrogeologi secara alami dapat menyebabkan terjadinya pencemaran airtanah. Evaluasi potensi pencemaran airtanah dari suatu sumber pencemar dapat didasarkan oleh lima faktor lingkungan fisik (LeGrand, 1964 dalam Todd, 1980). Konsep yang dikembangkan LeGrand mengacu pada sumber pencemar dan sumur. Faktor lingkungan fisik yang dianggap mempengaruhi pencemaran airtanah adalah kedalaman muka airtanah, daya serap di atas muka airtanah, permeabilitas akifer, kemiringan muka airtanah, dan jarak horisontal dari sumber pencemar.

Sebaran spasial kedalaman muka airtanah menunjukkan kedalaman sumur-sumur yang terdekat dari SPBU 44.552.10 berkisar 0-6 m, lebih dangkal daripada daerah lainnya. Jarak vertikal antara dasar tangki timbun BBM di SPBU 44.552.10 dengan muka airtanah sumur di sekitarnya berkisar 1,2524,16 m. Rata-rata kedalaman ke muka airtanah dari dasar tangki pada 80 sumur adalah 9,7 m. Pada kasus penelitian ini sumber pencemarnya ada di dalam tanah, jadi semakin dangkal kedalaman muka airtanahnya, maka jarak vertikal antara sumber pencemar dengan muka airtanah semakin dekat. 
Sebagian besar sumur sampling di lokasi penelitian (57,5\%) memiliki tekstur tanah pasir bergeluh dengan daya serap tergolong tinggi. Dari peta tekstur tanah di lokasi penelitian dapat dilihat bahwa daya serap di zona vadose pada sumur-sumur yang terdekat dengan SPBU tergolong tinggi karena materialnya tanahnya di dominasi oleh kerikil kasar (batu dan kerikil). Hal ini mengindikasikan bahwa daerah sekitar SPBU (pada radius sekitar 0-1 km) tergolong rentan untuk tercemar apabila terjadi kebocoran BBM dari tangki timbun bawah tanah. Semakin kasar tekstur tanah pada media zona tak jenuh, maka semakin besar daya serap di atas muka airtanahnya, skornya semakin kecil, sehingga semakin besar potensinya untuk tercemar.

Sebagian besar sumur sampling di lokasi penelitian memiliki material akifer berupa pasir halus, yakni mencapai 53,75\% dan sebagian lagi (40\%) didominasi oleh campuran pasir kasar dan kerikil kasar. Sisanya (hanya sekitar 6,25\%) merupakan campuran antara lempung dan pasir . Hasil perhitungan pumping test didapatkan nilai konduktivitas hidrolik sebesar 2,06 m/hari, material penyusun akifer berupa pasir halus, permeabilitas akifernya termasuk dalam kategori sedang.

Dalam Bouwer (1978) disebutkan bahwa permeabilitas akifer jenis pasir halus memiliki kecepatan transport pencemar berkisar 1-5 m/hari. Lempung dan lempung berpasir hanya mampu maksimal 0,1-0,2 m/hari. Jenis pasir kasar dapat melalukan pencemar dengan kecepatan 20-100 m/hari. Kerikil kasar merupakan jenis yang paling cepat dapat melalukan zat pencemar di lokasi penelitian yakni hingga $100 \mathrm{~m} /$ hari. Dari hasil perhitungan diketahui bahwa gradien hidrolik daerah penelitian berkisar 0,005-0,07. Kecepatan transport pencemar mencapai 0,013-0,144 m/hari. Kecilnya nilai ini disebabkan nilai konduktivitas hidrolik diperoleh dengan slug test. Daerah penelitian merupakan daerah pemukiman padat penduduk, sehingga sering dilakukan pemompaan pada sumur. Hal ini mengakibatkan airtanah turun drastis, meskipun waktu kembalinya muka airtanah pada posisi semula tergantung material di daerah penelitian.

Kecepatan dan arah aliran airtanah sangat menentukan kemampuan air dalam melarutkan polutan. Kemampuan airtanah mengalir melalui batuan tergantung pada permeabilitas batuan (Todd, 1980). Berdasarkan hasil penelitian MacDonald and Partners (1984), lokasi penelitian memiliki permeabilitas sekitar 5-20 m/hari dengan gradien hidrolik sebesar 0,00678-0,00758, sehingga kecepatan airtanah berkisar $0,0339 \mathrm{~m} /$ hari hingga $0,1516 \mathrm{~m} /$ hari.

Secara umum arah aliran airtanah Daerah Istimewa Yogyakarta menuju ke selatan dan ke sungai yang terdekat (MacDonald and Partners, 1984). Secara alami, aliran airtanah akan memotong tegak lurus $\left(90^{\circ}\right)$ kontur airtanah dan mempunyai arah aliran dari muka airtanah tinggi menuju muka airtanah yang lebih rendah. Hal ini dipengaruhi oleh potensial gravitasi dan berlaku pada kondisi akifer yang homogen dan isotropis (Purnama, dkk, 2006). Freeze and Cherry (1979) menyatakan 
bahwa muka airtanah bebas dan arah aliran airtanah bebas dipengaruhi oleh topografi. Semakin tinggi ketinggian suatu tempat, maka semakin dalam pula muka airtanah bebasnya dan arah aliran airtanah bebas mengikuti topografi.

Kemiringan muka airtanah sumur-sumur di lokasi penelitian berkisar 0,5-7\%, dengan rata-rata kemiringan sebesar 1,7\%. Distribusi spasial kemiringan muka airtanah pada sumur-sumur sampling di lokasi penelitian dengan kisaran 2\%. Daerah yang airtanahnya berpotensi tercemar BBM dari SPBU 44.552.10 memiliki kemiringan muka airtanah 0-2\%. Sumur dengan persentase kemiringan muka airtanah yang tinggi dan searah dengan aliran airtanah SPBU memiliki potensi yang besar untuk tercemar. Sumur dengan persentase kemiringan muka airtanah yang relatif rendah dan searah dengan aliran airtanah dari SPBU masih berpotensi untuk tercemar. Kemiringan muka airtanah sumur-sumur pada daerah yang berpotensi mengalami pencemaran BBM dari SPBU 44.552.10 relatif datar, yakni 0-2\%, sehingga menyebabkan kelas potensi yang ada relatif kecil.

Perembesan bensin dari tangki penyimpan terjadi secara bertahap, sehingga biasanya tidak diketahui dan tidak terdeteksi (Darmono, 2001). Polutan ini bergerak secara vertikal melalui profil tanah dan secara horisontal melalui aliran air tanah (Franzmann, et al. 2002). BBM dalam bensin akan mengapung pada permukaan airtanah dangkal, mengalir mengikuti arah aliran airtanah. Sebagian BBM ada yang menguap dan ada yang mengalami biodegradasi oleh mikrobia (Notodarmodjo, 2005). Titik sampling sumur terdekat berada pada jarak 18,34 meter dari SPBU, dan titik terjauh 2131 meter dari SPBU. Titik sampling sumur terbanyak diambil pada radius 1-1,5 $\mathrm{km}$ dari SPBU. Potensi terbesar ada pada radius kurang dari $45 \mathrm{~m}$ di bagian selatan dan barat daya SPBU.

Airtanah di sekitar SPBU 44.552.10 terbukti memiliki potensi mengalami pencemaran BBM ditinjau dari aspek lingkungan fisik. Besar kecilnya potensi ini dapat berubah apabila ditinjau dari berbagai faktor lain yang lebih kompleks seperti konstruksi tangki, konstruksi areal penutup tangki, konstruksi sumur, perilaku petugas, aktivitas pemompaan sumur, dan sebagainya. Aktivitas pemompaan dapat sangat mempengaruhi arah aliran pencemar dalam airtanah karena kemiringan muka airtanah daerah penelitian relatif datar (Fetter, 1999). BBM yang bocor dari SPBU 44.552.10 bisa saja mengalir ke arah timur laut tegak lurus kontur airtanah. Hal ini terjadi apabila sumursumur di bagian utara mengalami pemompaan yang berlebihan yang menyebabkan muka airtanah turun dan kontur airtanah berubah.

Hasil penelitian menunjukkan bahwa potensi pencemaran BBM terhadap airtanah di sekitar SPBU 44.552.10 relatif kecil, namun perlu kita ingat bahwa minyak bumi dan produknya merupakan kelompok kontaminan hidrokarbon atau pencemar organik yang paling potensial. Sejalan dengan 
penggunaannya yang intensif terutama sebagai sumber energi, maka kemungkinan pencemaran oleh minyak bumi pada tanah dan airtanah menurut penulis tetaplah sangat besar. Dampaknya pada lingkungan (fisik, biotis, maupun sosial) dan kesehatan manusia juga perlu mendapat perhatian serius.

Kontaminan yang terkandung dalam tanah dan airtanah, terutama yang dikategorikan sebagai bahan beracun dan berbahaya (B3) mempunyai potensi dalam menyebabkan gangguan pada manusia dan lingkungan. Seringkali kontaminan dalam tanah dan airtanah terdapat dalam konsentrasi yang rendah dan sulit dideteksi. Banyak manusia yang tidak menyadari bahwa paparan yang menerus atau bersifat kronis dari suatu kontaminan akan mengakibatkan gangguan kesehatan yang baru dirasakan setelah bertahun-tahun. Paparan terhadap kontaminan yang berasal dari tanah dan airtanah dapat melalui mulut karena meminum air yang terkontaminasi, atau melalui pernapasan karena menghirup udara yang mengandung uap kontaminan tersebut (Notodarmojo, 2005).

\section{Kesimpulan dan Saran}

Dapat dikatakan bahwa sebagian besar wilayah di lokasi penelitian memiliki potensi kecil untuk mengalami pencemaran airtanah ditinjau dari aspek lingkungan fisik alami. Hasil penelitian menunjukkan sumur yang terletak 0-2 km di bagian selatan dan barat daya SPBU 44.552.10 berpotensi mengalami pencemaran BBM. Potensi terbesar berada pada radius $45 \mathrm{~m}$.

Sekecil apapun potensi pencemaran BBM terhadap airtanah di sekitar SPBU tetap harus diwaspadai, sebab jika terjadi pencemaran tetap akan menimbulkan dampak negatif bagi warga yang sumurnya berpotensi terkena imbas dari pencemaran tersebut. Proses pembersihan pencemaran BBM di lingkungan sukar dilakukan, memerlukan waktu lama, dan biaya yang besar. Sebaiknya SPBU terletak di kawasan yang airtanahnya dalam, tangki tidak dipendam terlalu dalam, dan tidak diurug langsung dengan tanah. Tangki pendam dapat dilapisi oleh material tahan bocor seperti beton dan semen untuk memperkecil risiko pencemaran terhadap airtanah.

\section{Daftar Pustaka}

Bouwer, H. (1978). Groundwater Hydrology. McGraw-Hill Book Company. New York: United States of America.

Darmono. (2001). Lingkungan Hidup dan Pencemaran: Hubungannya dengan Toksikologi Senyawa Logam. UI Press. Jakarta.

Fetter, C.W. (1999). Contaminant Hydrogeology. Prentice Hall, Upper Saddle River, New York. R. E. 
Franzmann, P.D., Robertson, W.J., Zappia, L.R., and Davis G.B. (2002). The role of microbial population in containment of aromatic hydrocarbons in the subsurface. Biodegradation. 13(1):65-78.

Freeze, R.A. and Cherry, J.A. (1979). Groundwater. Prentice-Hall, Inc. Englewood Cliffs. New Jersey.

Kamil, I.M. (2004). SPBU, Bukan Persoalan Sepele. Pikiran Rakyat Online: 26 Oktober 2004. http://www.pikiran-rakyat.com/cetak/1004/26/0803.htm. Diakses tgl 24 Agustus 2006.

Mac Donald and Partners. (1984). Greater Yogyakarta Groundwater Resources Study. Volume 3: Groundwater. Directorate general of Water Resources Development, Groundwater Development Project (P2AT).

Notodarmojo, S. (2005). Pencemaran Tanah dan Air Tanah. Penerbit ITB.

Purnama, I.S. (2000). Bahan Ajar Geohidrologi. Fakultas Geografi. Universitas Gadjah Mada. Yogyakarta.

Soemirat, J. (2005). Toksikologi Lingkungan. Cetakan ke-2. Gadjah Mada University Press. Yogyakarta.

Todd, D.K. (1980). Groundwater Hydrology. Second edition. John Wiley and Sons. Inc, New York. 